\title{
Ozone rules prompt dispute over speed limits
}

Munich. The German state (Land) of Hessen introduced the country's first ever motorway speed limits last week in an attempt to reduce tropospheric ozone levels that have reached record levels in central Europe's prolonged period of hot, still weather.

But the speed restrictions - $90 \mathrm{~km}$ (58 miles) an hour on motorways, and $80 \mathrm{~km}$ an hour on other roads - have caused a political uproar. The federal environment minister, Klaus Töpfer, says that they will have a negligible effect on ozone levels, and describes the action as "politically motivated".

Similarly the federal transport minister, Matthias Wissmann, called the decision "unjustified", an opinion shared by local businessmen who are challenging the actions of Hessen - which, in contrast to the conservative federal government, is run by a coalition of Social Democrats and Greens - in the state constitutional courts.

In common with Germany's other 15 Länder, Hessen has the right under the federal law that controls emissions to take steps to prevent the formation of winter smog, including the imposition of limits on traffic speeds. Hessen's environment minister, Joschka Fischer, a prominent member of Germany's Green Party (die Grünen) has interpreted this law as applying to summer

Winter smog occurs in anticyclones when pollutants, particularly nitrogen oxides, accumulate in a thin layer of cold air trapped by a temperature inversion in which the mixing of air-mass - either horizontally or vertically - is impeded. Anticyclones can also precipitate summer smog through the lack of lateral air movements alone, and in smog as well.

sunny conditions ozone is produced from the pollutants.

Traffic contributes to concentrations of ozone when NO released in exhaust fumes is oxidized to $\mathrm{NO}_{2}$. During daylight hours, sunlight splits $\mathrm{NO}_{2}$ and the released oxygen atoms combine with molecular oxygen $\left(\mathrm{O}_{2}\right)$ to form ozone $\left(\mathrm{O}_{3}\right)$. If the process takes place during a low exchange of air-mass, ozone can accumulate to levels that are biologically damaging.

Peak ozone levels of more than $215 \mu \mathrm{g}$ $\mathrm{m}^{-3}$ ("first warning levels") were measured at 11 stations in Hessen last week. As no change was forecast in the prevailing weather conditions, the state decided to introduce the speed limits. They were maintained for three days.

According to police reports, 85 per cent of drivers complied with the restrictions on the first day, and most of the rest drove more slowly than usual. Compliance improved still further over the days; normally 17 per cent of Hessen's drivers travel at more than $160 \mathrm{~km}$ an hour on motorways.

Peak ozone levels fell significantly after imposition of the speed limits. But Karlheinz Liebl from the Hessen Environment $\mathrm{Bu}$ reau, which is responsible for the measurements, says that the precise extent to which the speed restrictions contributed to this fall will be known only after detailed analysis of all contributory factors.

Hessen officials are confident that, on the basis of the results of the few studies that have been carried out, speed limits are likely to have been responsible for a fall of between one and three per cent in ozone levels over this period.

\section{Berlin ends medical school clash}

Berlin. A fierce dispute over the organization of medical teaching and research in Berlin has ended with the decision to transfer the Rudolf Virchow university clinic of west Berlin's Free University to east Berlin's Humboldt University, where it will be merged with the Charité university clinic.

The transfer will take place next spring, and is the result of a decision by the Berlin government taken after consultation with the universities involved - after months of increasingly ugly wrangling (see Nature 369, 431; 1994).

The roots of the conflict lie in the fact that, after reunification in 1990 , Berlin found itself with three university medical schools (the third, known until recently as the Steglitz clinic, also belongs to the Free University), which it could not afford to maintain. Under the merger, the total number of teachinghospital beds in the city will be reduced, and the annual intake of medical students will fall from 1,000 to 600 .
Angry at the prospect of losing twothirds of its preclinical students, the Free University last month embarked on a lastminute publicity campaign to avert the merger.

All teaching staff at the Charité, as in other universities of the former East Germany, have already had to reapply for their jobs as part of a restructuring process and Konrad Seppelt, vice-president for science and research at the Free University, admits that his institution would have readily accepted the merger if it had happened before posts at the Charité had been reaffirmed. But, not surprisingly, the Charite has been offended by the Free University's implication that the Charité should bear most of the staff cuts.

Cornelius Frömmel, the Charité's director of research, also believes that fear of competition from the strengthened Charité could also underlie the Free University's hostility to the merger.

Alison Abbott

\section{IMAGE UNAVAILABLE FOR COPYRIGHT REASONS}

\section{Germany's transport minister calls restrictions on cars 'unjustified'.}

But Töpfer remains unenthusiastic about temporary measures to control ozone levels. $\mathrm{He}$ says that serious reductions can be achieved only by reducing production of nitrogen oxides at source. One measure would be the wider introduction of catalytic converters, which reduce output of pollutants by 90 per cent (half of Germany's cars are already fitted, one of the highest rates in Europe)

Another step, he says, would be the introduction of vapour recovery systems in petrol stations to prevent gases from fuel pumps drifting into the atmosphere when cars are being filled. The European Commission has prepared a directive that would require such systems in all forecourt pumps.

Walter Fricke, an ozone expert at the Hessen environment ministry, accepts that such measures are necessary. But he argues that they will take time to introduce. Meanwhile, he says, any measure taken to reduce ozone is important.

The environment minister of neighbouring Lower Saxony has drafted a bill that introduces similar measures to control summer smog. But it goes even further than Hessen. At a second ozone warning level $\left(360 \mu \mathrm{g} \mathrm{m}^{-3}\right.$, the state would forbid the use of any car without a catalytic converter. "We wanted to do this in Hessen, but didn't dare," says Fricke. Hessen is awaiting the outcome of a court challenge to its right to impose speed limits. If it wins, it will consider going the way of Lower Saxony.

But apart from Lower Saxony, which has a Social Democrat government, Fischer has few supporters among the other Länder. The environment minister in right-wing Bavaria, for example, called Hessen's action a result of "major hysteria".

Alison Abbott 